\title{
Technology-enhanced formative assessment in higher education: A voice from Indonesian EFL teachers
}

\author{
1'Roghibatul Luthfiyyah*, ${ }^{2}$ Aisyah, ${ }^{3}$ Gunadi Hary Sulistyo \\ 1, 2 English Education Department, FKIP, \\ Universitas Swadaya Gunung Jati, Cirebon, Indonesia \\ ${ }^{3}$ English Education Department, FS, Universitas Negeri Malang, Indonesia
}

\author{
*Corresponding Author \\ Email: roghibatul.luthfiyyah@gmail.com \\ Received \\ Revised: \\ Accepted: \\ Published: \\ 13 October 2020 \\ 11 February 2021 \\ 27 February 2021 \\ 28 February 2021
}

\begin{abstract}
The integration of information communication and technology in language teaching has been intensely examined in literature works. However, the study which explicitly investigates the advancement of technology for language assessment in higher education level is still underexplored, particularly in a formative assessment area. To fill that gap, the present study aims at investigating the perceptions of EFL teachers towards technology-enhanced formative assessment and how they implement it in the classroom. This study employs a qualitative case study approach. Of three participants from different universities were voluntarily participated in a semi-structured interview. The interview seeks to investigate the perceptions of teachers towards technology-enhanced assessment, the roles of technology in formative assessment, and the impact of technology on language learning. The findings reveal that EFL teachers view formative assessment as well as technology in a positive perception. They admit that technology is a practical tool that has multiple roles and it is deemed as useful and meaningful platform for assessing students. Finally, technologyenhanced formative assessment gives an impact on students' performance, particularly on language accuracy. The further implications are discussed in this paper.
\end{abstract}

Keywords: technology-enhanced formative assessment; teachers' voice; higher education; formative assessment

\section{INTRODUCTION}

As the integration of technology in language teaching and learning becomes extensively proliferated, there is also a growing interest in adopting technology to promote language assessment in the classroom practices (Bennett, Dawson, Bearman, Molloy, \& Bound, 2017; Deeley, 2018; Webb \& Ifenthaler, 2018). The range of technology tools offers promising merits to assist teachers in assessing their students meaningfully. However, some scholars admit that the adoption of technology in assessment is a complex process affected by individual, contextual, and technical factors (Brady, Devitt, \& Kiersey, 2019; 
Edulite Journal of English Education, Literature, and Culture

Vol. 6, No. 1, February 2021, pp. 42-54

E-ISSN: 2528-4479, P-ISSN: 2477-5304

http://jurnal.unissula.ac.id/index.php/edulite DOI: http://dx.doi.org/10.30659/e.6.1.42-54

Koc, 2013). Mimirinis (2019) correctly points out that teachers' decision to utilize technology for assessment practices depends on their belief: What benefits they will perceive from the tools, how technology can facilitate the assessment purposes, and how technology can enhance the learners' engagement through timely and constructive feedback. Thus, it is notable for examining further the teacher's personal perceptions on technology-enhanced formative assessment in a specific context.

The seminal work from Black and Wiliam (2009) embarks the shifting paradigm of educational assessment, highlighting the importance of practising formative assessment. It refers to the classroom assessment practice by eliciting the evidence of learners' achievement, interpreting the results, and using them to make decisions about the next teaching instruction and to inform the students where they are and how they can achieve learning goals through informative feedback. It is emphasized that providing constructive feedback is a crucial element in the formative practice, which potentially bridges the gap between the students' current level competence and the expecting learning target. Besides, timely feedback can activate the students' autonomy and metacognition in learning. It can also assist teachers in reflecting their pedagogical knowledge to adjust their teaching quality (Chong, 2018; Dalby \& Swan, 2019; Sheard \& Chambers, 2014).

The capacity of technology in obtaining and processing extensive data swiftly helps teachers reduce their workload in undergoing formative assessment practice (Dalby \& Swan, 2019; Ningsih \& Mulyono, 2019). Digital technology also imparts automated feedback to students' work in which they can independently reflect their learning progress. A current study conducted in higher education reports that the implementation of regular formative eassessment promotes the learners to monitor their progress, motivate them to study, and elevate the students' perceptions towards their learning. Besides, teaching staff also obtains the positive effect of formative e-assessment. They admit that they gain insight from the learners' progress that can be used as a reflection to redesign a better teaching delivery (McCallum \& Milner, 2020).

Several studies in the Indonesia context, however, typically report that Indonesian teachers have an inadequate understanding of formative assessment, and they tend to have difficulty in implementing their knowledge of formative assessment into practices due to socio-cultural factors (Arrafii \& Sumarni, 2018; Azis, 2015; Puad \& Ashton, 2020). The prevalent assessment practices found are examination, test, passive role of students, and other assessments for accountability purposes. The culture of high-stake examination dominantly manifested the teachers' perceptions on the prominent examination as a decision-maker for the prospects of the learners (Deneen et al., 2018). Although several empirical studies have been investigated in secondary-level contexts, a similar study is rarely found in higher education level settings.

Despite the demand for assessing the implementation of formative assessment in higher education, it is also attempting to scrutinize teachers' voice in utilizing technology in ELT formative assessment practice. In general ELT context, (Rodliyah, 2018) reports her qualitative study that ELT teachers have self-interest and positive attitude towards the use of ICT in teaching for several reasons. They also believe that ICT promotes some advantages to 
Luthfiyyah, R., Aisyah, \& Sulistyo, G. H. (2021). Technology-enhanced formative assessment in higher education: A voice from Indonesian EFL teachers. EduLite: Journal of English Education, Literature, and Culture, 6 (1), 42-54. http://dx.doi.org/10.30659/e.6.1.42-54

assist their teaching process. Another empirical study from (Safitry et al., 2015) reveals that most of the teachers in Indonesia have a positive perceptions of ICT integration in the classroom, even though they are struggling with the limited technical support and lack of digital technology literacy. The previous studies briefly depict the lively interest of teachers in using technology in teaching and learning practice. However, the discussion on how teachers perceive technology integration in a specific practice of formative assessment in higher education level is still under scrutiny. Following that gap, this study intends to investigate the Indonesian EFL teachers' perception of technology-enhanced formative assessment at the tertiary level. We confine the term of teachers' perceptions in this study as teachers' belief on the purposes and values of technology-enhanced formative assessment. Thus, the present study focuses on examining EFL teachers' perceptions towards formative assessment, identifying the roles of technology in formative assessment perceived by EFL teachers, and highlighting the impact technology-enhanced formative assessment on students' language learning.

\section{METHOD}

This study adopts a qualitative case study that endeavors to explore real-life, individual insights, multiple cases through a detailed and in-depth collection of data from multiple sources of information (Yin, 2018). This method is pertinent to the objective of the study that attempts to investigate Indonesian EFL teachers' perceptions of how they perceive and practice technologyenhanced formative assessment in higher education. The present study describes qualitatively the perceptions of EFL teachers towards technologyenhanced formative assessment, which eventually can be a meaningful suggestion for language classroom assessment practices in university.

\section{Participants and context}

The participants of the study were recruited purposively based on a set of criteria. First, they are an experienced teacher who has more than three years of teaching experience. Second, they ever attended some assessment or technology professional training. Third, they utilize technology for formative assessment purpose. Fourth, they agree to be entangled in this research approved by signing the consent form offered. Those criteria are intended to be set in order to select the prospective participants. The first pool of participants was taken from a list of national conference attendees who have adequate teaching experience, assessment literacy, and digital knowledge. From the potential teachers who were sent the consent letter via email, three EFL teachers sent back the consent forms as the confirmation that they voluntarily agree to participate in this study. The three participating teachers, Dewi, Dimas, and Sinta (all names are pseudonyms), are from three different universities in West Java and Central Java. One of the participants is a faculty member of the state university, and the rests are from private universities. They also teach different subjects of English language teaching. Table 1 illustrates the further information of the participants. Besides, since all the universities are located in Java, one of the established islands in Indonesia, the technology facility is not a big issue for many institutions. Many students 
have their gadgets (e.g., smartphone, tablet, or laptop) and one of the private universities provides their students' internet connection facility.

Table 1. Personal Information of the Participants

\begin{tabular}{lllll}
\hline No & Participants & Dewi & Dimas & Sinta \\
\hline 1 & Gender & Female & Male & Female \\
\hline 2 & Age & 35 Years Old & 45 Years Old & 32 Years Old \\
\hline 3 & Subject & General English & $\begin{array}{l}\text { Reading } \\
\text { Comprehension }\end{array}$ & $\begin{array}{l}\text { Academic } \\
\text { Writing }\end{array}$ \\
\hline 4 & Institution & $\begin{array}{l}\text { State } \\
\text { University }\end{array}$ & $\begin{array}{l}\text { Private } \\
\text { University }\end{array}$ & $\begin{array}{l}\text { Private } \\
\text { University }\end{array}$ \\
\hline 5 & $\begin{array}{l}\text { Teaching } \\
\text { Experience }\end{array}$ & Seven years & Ten years & Four years \\
\hline 6 & $\begin{array}{l}\text { Technology and } \\
\text { Assessment Training } \\
\text { Experience }\end{array}$ & Yes & Yes & Yes \\
\hline
\end{tabular}

\section{Data Collection}

To obtain rich and detailed qualitative information to understand the EFL teachers' point of view about technology-enhanced formative assessment and its implementation, one-to-one semi-structured interviews were conducted to each participant. An interview protocol was prepared to ensure that all participants get the same principal questions and assist the interviewer in maintaining the flow of discussion. Some open-ended questions addressed to highlight the purposes of classroom assessment conducted by the participants, kinds of technology utilized in formative assessment, the role of technology to enhance formative assessment, and the benefits of technologyintegrated formative assessment towards the students' learning improvement. The individual interviews were informally held by using telephone twice in a month based on the participants' convenient time. To avoid misunderstanding and to reduce the tension, the interview was conducted in around $30-45$ minutes by using Bahasa Indonesia. Finally, the interview sessions were fully audio-recorded, transcribed, translated into English, and sent back to the participants to get verification.

\section{Data Analysis}

A set of interview data that were obtained from there different participants were treated equally prominent. They were firstly transcribed verbatim and translated into the English language. Then the transcripts were repeatedly read to conceive the holistic phenomena of the study (Yin, 2017). When the data were contained a phrase or statement related to research questions, they were highlighted and marked as an initial coding. Then the codes were categorized into axial coding to recognize main categories that are closely related to research questions. Some categories are the purpose of assessment, the roles of technology in formative assessment, and the way technology can assist students in learning. Furthermore, the data were depicted and elaborated in the narrative form. The EFL teachers' perceptions and practices of technology-enhanced formative assessment were interpreted based on the data gathered and supported by some relevant theories and previous literature before it concludes. 
Luthfiyyah, R., Aisyah, \& Sulistyo, G. H. (2021). Technology-enhanced formative assessment in higher education: A voice from Indonesian EFL teachers. EduLite: Journal of English Education, Literature, and Culture, 6 (1), 42-54. http://dx.doi.org/10.30659/e.6.1.42-54

\section{FINDINGS AND DISCUSSION Findings}

The findings from the open-ended interview are presented into three main key themes to address the research questions: 1) teachers' perceptions about formative assessment; 2) the roles of technology in formative assessment; 3) the impact of technology-enhanced formative assessment on students' learning. The themes are presented respectively.

\section{Teachers' perceptions towards formative assessment}

As the starting point, we attempted to grasp the teachers' perceptions towards formative assessment before we discussed further the roles of technology in formative assessment. Perceptions of teachers towards formative assessment encompass what teachers believe in the purpose of formative assessment and how they value formative assessment activity in teaching and learning process. Overall, participants perceive positively about formative assessment. They share opinions that formative assessment has tangible purposes that can constructively impact the improvement of students' learning. The primary purpose of formative assessment is to check the students' understanding of learning. However, the participants typically value formative assessment merely as an essential activity to elicit the information of the students' progress in learning and to motivate and engage them in learning rather than as a reflection for teachers to assess their teaching instruction.

"Formative assessment is an important activity to check my students' understanding of learning. It can be a brainstorming activity, a quiz, discussion, or project. Those activities can motivate my students to learn more and engage in the teaching and learning process." (Dewi, FAP).

"... to check whether my students got the point of the materials I delivered, I often give a quiz, discussion, a direct question to my students or let them conduct peer-assessment by giving comments or score towards their friends' work. Besides, it assists my students to know their strength and weaknesses in learning so that they can reflect their progress ability." (Dimas, FAP).

"My favorite formative assessment activity is giving an online quiz. Using some apps for an online quiz, it's fun and interesting. My students actively engage in the activity. They do not realize that the activity is to assess their knowledge. They feel that it is just a game. However, I get benefits from this activity; I can easily capture my students' ability." (Sinta, FAP).

Formative assessment and feedback are interchangeable. Feedback in formative assessment aims at helping students to step forward to achieve the learning goals and assessing teacher's instruction to enhance the quality of teaching. In this case, there are some facts revealed in the interview. First, the teacher is considered as a single source that provides feedback for students' 
work. When the opportunity to give comment or feedback is offered to the students, they tend to give positive feedback to their friends' work rather than to give an honest comment. Another fact is that teachers hurdle in bestowing one to one feedback to their students due to a significant number of students they have in one class. Thus, they prefer to use the online quiz as an appealing activity for formative assessment since it can provide instant, timely, and automatic feedback. Besides, online quiz contains a gamification aspect that can motivate the students in doing the assessment.

"Yes, feedback is one of the essential activities in formative assessment. My students will revise their work based on the feedback I gave them." (Dewi, FAP2).

"Giving individual feedback is challenging for me since I have a large class. It takes much time to do it. Sometimes, I allow my students to comment to each other to reduce my burden in giving feedback. However, they only praise their friends' work; they are reluctant to give critique or negative comment." (Dimas, FAP2).

"Yes, from online quiz my students will get personal feedback automatically. It helps me a lot. Otherwise, I need to spend my time to correct my students' work." (Sinta, FAP2)

The perceptions of participants towards formative assessment purpose are relatively typical. They perceive formative assessment as a meritorious activity that can assist students in achieving the learning goals. Furthermore, they also appraise feedback as decisive activity in formative assessment aiming at promoting learning quality. However, they reflect that peer-feedback activity is less effective to be implemented rather than teachers' feedback or automatic feedback facilitated by technology.

\section{The roles of technology in formative assessment}

After portraying teachers' perceptions towards formative assessment, the second theme highlights the roles of technology in the context of formative assessment. As technology becomes more pervasive in language assessment, particularly in classroom assessment, due to its merits, teachers perceive that technology has multiple roles in formative assessment practice. They assert that technology can assist them in some ways, such as workload efficiencies, providing feedback, and facilitating students' engagement and independent learning.

For some teacher, especially the ones who have a big class, checking, correcting, and grading students' work every week is fatiguing. It is time consuming when teachers have to check over a stack of papers and to give comment one by one. Meanwhile, other teaching tasks are awaiting to be handled. All participants admit that using technology in the formative assessment, such as online quiz assist them effectively in providing instant feedback and quick score. The finding is aligned with the teachers' preference in providing feedback for large classes. An automatic or a real-time formative assessment feedback effectively saves their time to check the students' work. 
Luthfiyyah, R., Aisyah, \& Sulistyo, G. H. (2021). Technology-enhanced formative assessment in higher education: A voice from Indonesian EFL teachers. EduLite: Journal of English Education, Literature, and Culture, 6 (1), 42-54. http://dx.doi.org/10.30659/e.6.1.42-54

"Technology can give swift score and feedback. It helps me a lot." (Dewi, TR1).

"...of course, an online quiz can give very quick feedback, and I don't need to check my students' work one by one. It saves my time."(Sinta, TR1).

Another role of technology in formative assessment is that it can facilitate feedback from teachers, peer, and department staff. With the assistance of technology, teachers can provide personalized feedback to the students in order to monitor their learning improvement and to guide them in achieving learning goals. The first participant, Dewi, shares her experience in practicing formative assessment using social media. She asks the students to submit their projects in social media, such as Instagram or Facebook group. Then, she invites other students and lecturers to give some comment towards the students' project. The comment should be focused on some interesting points and things to be improved. Finally, the student should positively ponder the suggestion and comment from their friends to revise their project. Although, the process is quite long and challenging, she can monitor the progress of the students' work quickly, and the students obtain authentic feedback from their friends. On the other hand, Dimas expresses that he often gives feedback to his students using some funny memes and voice note, instead of score or written comment. It is exciting and motivating the students to notice their strengths and weaknesses.

Furthermore, the interviewees also admit that technology facilitates the students to study collaboratively and independently. In this case, Sinta expressed her teaching experience in an academic writing class. She asked the students to work in a small group to compose an academic text using Google Docs. The app offers some collaborative features to facilitate students' brainstorming activity, sharing the references, editing the draft, and giving comments and feedback. It is like the students write together in one virtual paper. They can write their idea, edit their work simultaneously, and see what changes made by their friends. The teacher also can monitor all the activities while the students are doing their work. Sinta affirms that the activity can encourage the students to have interaction, respect other's opinion, and motivate the students to learn independently.

\section{The impact of technology-enhanced formative assessment}

Although all participants view technology as worthwhile for formative assessment activities, the goal of achieving workload efficiencies often comes first before the impact of technology integration on pedagogy or students' language learning. However, this part attempts to discuss further the effect of technology on students' learning as a reflection of the way teachers utilize technology in formative assessment settings. Overall, participants noted that the integration of technology in formative assessment gives some impact on students' performance, specifically language accuracy.

An online quiz, such as Kahoot, Quizizz, Quizlet, and Socrative apps, is the most prevalent platform used by the teachers. It facilitates pre-test, post- 
EduLite Journal of English Education, Literature, and Culture

Vol. 6, No. 1, February 2021, pp. 42-54

E-ISSN: 2528-4479, P-ISSN: 2477-5304

http://jurnal.unissula.ac.id/index.php/edulite DOI: http://dx.doi.org/10.30659/e.6.1.42-54

test, or daily exercises to check students' understanding of the material. Dewi reports that providing an online quiz as daily exercise potentially retains students' performance with fun and challenging vibes. The sense of competition in online quiz stimulates learners to be more engaged and motivated in learning. Thus, students make a good effort to be the best player in an online quiz. In addition, Dimas emphasizes that compared to traditional exercise; the use of digital game-based exercise can lower students' tension. Most of the students are commonly anxious and frustrated when they face a test, but digital game-based test offers more interactive and entertaining task environment that makes students enjoy the process that might promote their learning performance.

One of the useful features of formative assessment digital tools is automated or instant feedback. It assists the students to realize their learning strengths and weaknesses. Some platforms provide the correct answers with complete explanations and others merely show the answer on the screen. Sinta expresses her experience of using Google Docs for collaborative writing. The app really helps my students to avoid grammatical and spelling issues. Once they write misspelling words or grammatical mistakes, the app detects them automatically and highlights the words as well as the revisions. She believes that her students acquire how to make a structured sentence from the feedback provided by the app. It also indirectly increases the students' awareness of language accuracy in the next writing task. Furthermore, detecting language accuracy using apps can decrease teachers' workload in correcting students' writing; teachers can focus more on content and discourse than language accuracy.

Despite the impact of technology on language accuracy, participants agree that integrating technology in formative assessment setting facilitates learners to work collaboratively, engage on the task, and develop learning responsibility that drives them to independent learners. However, some of them are unsure how technology integration in formative assessment affects not only language accuracy or some lower cognitive level, but also language use and higher cognitive level. They admit that they require updating their technological as well as pedagogical knowledge due to the dramatic development of technology use in teaching, particularly for assessment purposes.

\section{Discussion}

Assessment plays a crucial role in the teaching and learning process. It is an activity for gathering information about students' learning progress and measuring their achievement. Although the mainstream conceptions of assessment, especially in Indonesia, focus on students' accountability rather than students' progress in learning, the current works of literature begin to highlight the positive effect of formative assessment towards student's learning improvement (Retnaningsih, 2013). Simultaneously, the omnipresent of technology use in education supports assessment practices in some ways. As a result, increased attention to technology-enhanced formative assessment becomes the captivating area to be explored. Thus, this study sets out to investigate the EFL teachers' perspective towards technology-enhanced formative assessment and its practice. 
Luthfiyyah, R., Aisyah, \& Sulistyo, G. H. (2021). Technology-enhanced formative assessment in higher education: A voice from Indonesian EFL teachers. EduLite: Journal of English Education, Literature, and Culture, 6 (1), 42-54. http://dx.doi.org/10.30659/e.6.1.42-54

The first issue discussed is about the purpose of formative assessment. The result of the interview shows that the teachers view formative assessment as a positive activity in learning. However, the teachers' conception of formative assessment objective remains patchy. They merely consider formative assessment as an effort to monitor the students' learning progress and to motivate them in learning. Black and Wiliam (2010) argue that the aim of formative assessment is more than enhancing students' learning, but also providing useful information for teachers to reconstruct their teaching instruction. The data come from the formative assessment can be a reflection for students to know their strengths and weaknesses. The teacher then assists them in achieving the learning goal by giving constructive feedback. Besides, through the implementation of formative assessment, the teacher also can reflect the teaching instructions implemented. Once the teaching technique does not work well, then they can rearrange the instruction based on the students' need.

A study from Arrafii and Sumarni (2018) confirms that the teachers who participated in their study have poor formative assessment literacy due to lack of exposure on how to conduct a formative assessment. They are relatively more familiar with the purpose of summative assessment than formative assessment. Two recent studies from Hasim et al., (2018) and Puad and Ashton (2020) emphasize that the teachers have a general lack of knowledge on the purpose of formative assessment and how to practice it. It happens due to limited exposure to formative assessment, the students' attitude towards assessment, and the teachers' power in the assessment. As a consequence, teachers tend to practice more summative assessment than formative assessment in their class. The result of this study is similar to the previous study. Although teachers relatively have a positive perception of formative assessment, they do not have sufficient understanding of the formative assessment conceptions. Some training or courses which discuss more on formative assessment knowledge and practice should be systematically conducted to update teachers' insights (Siregar \& Amalia, 2019).

Furthermore, in the implementation of classroom-based assessment, technology also plays a role to enhance the effectiveness of formative assessment practice. In this case, three participants admit that technology has multiple roles in supporting formative assessment. They are workload efficiency, facilitating feedback, and facilitating collaborative and independent learning. The teachers confess that checking, editing, and providing feedback to students' work is time-consuming. This problem occurs, especially in the large class. The online quiz offers automatic and instant feedback to students' work that eases teachers to set up the administration of the formative assessment. The finding is similar to the result of a study from Brady et al., (2019) that points the role of technology as a workload of efficiency, a medium for transparency and visibility of students' work.

Bawa (2018) and Mahbub (2020) report that the use of online quiz such as Kahoot, Quiziz, and Socrative facilitates learning engagement that potentially promotes students' performance, as well as motivation and focus in learning. Another study from (Alexiou \& Paraskeva, 2010) reveals that through e-portfolio students can develop self-regulated learning and their academic skills. Additionally, Mimirinis (2019) interviewed the academic staff at the 
EduLite Journal of English Education, Literature, and Culture

Vol. 6, No. 1, February 2021, pp. 42-54

E-ISSN: 2528-4479, P-ISSN: 2477-5304

http://jurnal.unissula.ac.id/index.php/edulite DOI: http://dx.doi.org/10.30659/e.6.1.42-54

university in her study. The finding classifies the roles of technology in eassessment into four types; as streamlining the process of assessment, as a facility for students' engagement, as a learning improvement, and as a communication development. Thus, technology in assessment is undoubtedly regarded as a useful and meaningful platform.

On the other hand, the impact of technology on students' learning needs more explorations. The participants express that generally technologyenhanced formative assessment elevates the students' language learning, particularly in language sub-skill (e.g., grammar and vocabulary). Comparing to the earlier studies, some learning aspects can be facilitated by technology integration. The first study explores that mobile-assisted language assessment can facilitate learners to communicate verbally, even though communication is less authentic (Tarighat \& Khodabakhsh, 2016). Furthermore, Ebadi and Rahimi (2019) reveal that a synchronous dynamic assessment using Google Doc enables students to develop their task achievement, coherence, and cohesion, lexicon, and grammar. Accordingly, EFL teachers should take consideration to explore further some aspect of language learning development from the implementation of technology-enhanced formative assessment.

\section{CONCLUSION}

The present study reveals that Indonesian EFL teachers in higher education positively perceive technology as a means of formative assessment enhancement. They undoubtedly admit that technology has various roles in assisting them in practicing formative assessment. However, EFL teachers need more extensive exposure to formative assessment knowledge, purposes, and practices. Additionally, some exploration of the impact of technology on students' language learning improvement should be taken into further consideration. Due to the limited size of participants involved in this study, it is suggested for the future research to conduct the study in a larger scale. Various factors underpinning the teachers' practice on technology-enhanced formative assessment, such as teachers' literacy and conceptions on formative assessment, the socio-cultural and policy factors are worthwhile to be examined extensively. Besides, technology-enhanced formative assessment from students' point of view is also compelling to be investigated.

\section{ACKNOWLEDGEMENTS}

This research is funded by Lembaga Penelitian Universitas Swadaya Gunung Jati Cirebon Jawa Barat Indonesia. 
Luthfiyyah, R., Aisyah, \& Sulistyo, G. H. (2021). Technology-enhanced formative assessment in higher education: A voice from Indonesian EFL teachers. EduLite: Journal of English Education, Literature, and Culture, 6 (1), 42-54. http://dx.doi.org/10.30659/e.6.1.42-54

\section{REFERENCES}

Alexiou, A., \& Paraskeva, F. (2010). Enhancing self-regulated learning skills through the implementation of an e-portfolio tool. Procedia - Social and Behavioral Sciences, 2(2), 3048-3054. https://doi.org/10.1016/j.sbspro.2010.03.463.

Arrafii, M. A., \& Sumarni, B. (2018). Teachers' Understanding of Formative Assessment. Lingua Cultura, 12(1), 45. https://doi.org/10.21512/lc.v12i1.2113.

Azis, A. (2015). Conceptions and practices of assessment: A case of teachers representing improvement conception. TEFLIN Journal - A Publication on the Teaching and Learning of English, 26(2), 129. https://doi.org/10.15639/teflinjournal.v26i2/129-154.

Bawa, P. (2018). Using Kahoot to inspire: Journal of Educational Technology Systems. https://doi.org/10.1177/0047239518804173.

Bennett, S., Dawson, P., Bearman, M., Molloy, E., \& Boud, D. (2017). How technology shapes assessment design: Findings from a study of university teachers: How technology shapes assessment design. British Journal of Educational Technology, 48(2), 672-682. https://doi.org/10.1111/bjet.12439.

Black, P., \& Wiliam, D. (2009). Developing the theory of formative assessment. Educational Assessment, Evaluation and Accountability, 21(1), 5-31. https://doi.org/10.1007/s11092-008-9068-5.

Black, P., \& Wiliam, D. (2010). Inside the black box: Raising standards through classroom assessment. Phi Delta Kappan, 92(1), 81-90. https://doi.org/10.1177/003172171009200119.

Brady, M., Devitt, A., \& Kiersey, R. A. (2019). Academic staff perspectives on technology for assessment (TfA) in higher education: A systematic literature review. British Journal of Educational Technology, 50(6), 3080-3098. https://doi.org/10.1111/bjet.12742.

Chong, S. W. (2018). Three paradigms of classroom assessment: Implications for written feedback research. Language Assessment Quarterly, 15(4), 330-347. https://doi.org/10.1080/15434303.2017.1405423.

Dalby, D., \& Swan, M. (2019a). Using digital technology to enhance formative assessment in mathematics classrooms. British Journal of Educational Technology, 50(2), 832-845. https://doi.org/10.1111/bjet.12606.

Dalby, D., \& Swan, M. (2019b). Using digital technology to enhance formative assessment in mathematics classrooms: Using digital technology in formative assessment. British Journal of Educational Technology, 50(2), 832-845. https://doi.org/10.1111/bjet.12606.

Deeley, S. J. (2018). Using technology to facilitate effective assessment for learning and feedback in higher education. Assessment \& Evaluation in Higher Education, 43(3), 439-448. https://doi.org/10.1080/02602938.2017.1356906.

Deneen, C. C., Brown, G. T. L., \& Carless, D. (2018). Students' conceptions of eportfolios as assessment and technology. Innovations in Education and Teaching International, 55(4), 487-496. https://doi.org/10.1080/14703297.2017.1281752.

Ebadi, S., \& Rahimi, M. (2019). Mediating EFL learners' academic writing skills in online dynamic assessment using Google Docs. Computer Assisted Language Learning, 32(5-6), 527-555. https://doi.org/10.1080/09588221.2018.1527362. 
Edulite Journal of English Education, Literature, and Culture

Vol. 6, No. 1, February 2021, pp. 42-54

E-ISSN: 2528-4479, P-ISSN: 2477-5304

http://jurnal.unissula.ac.id/index.php/edulite DOI: http://dx.doi.org/10.30659/e.6.1.42-54

Hasim, Z., Di, S., \& Barnard, R. (2018). Eliciting teachers' understanding and their reported practices on school-based formative assessment: Methodological challenges. Indonesian Journal of Applied Linguistics, 8(1). https://doi.org/10.17509/ijal.v8i1.11476.

Koc, M. (2013). Student teachers' conceptions of technology: A metaphor analysis. Computers \& Education, https://doi.org/10.1016/j.compedu.2013.04.024. $68, \quad 1-8$.

Mahbub, M. A. (2020). Learning English mediated by Kahoot: Insights from the Indonesian EFL instructors. Journal on English as a Foreign Language, 10(2), 246-267. https://doi.org/10.23971/jefl.v10i2.1917.

McCallum, S., \& Milner, M. M. (2020). The effectiveness of formative assessment: Student views and staff reflections. Assessment and Evaluation in Higher Education, O(0), 1-16. https://doi.org/10.1080/02602938.2020.1754761.

Mimirinis, M. (2019). Qualitative differences in academics' conceptions of eassessment. Assessment \& Evaluation in Higher Education, 44(2), 233-248. https://doi.org/10.1080/02602938.2018.1493087.

Ningsih, S. K., \& Mulyono, H. (2019). Digital assessment resources in primary and secondary school classrooms: Teachers' use and perceptions. International Journal of Interactive Mobile Technologies, 13(8), 167-173. https://doi.org/10.3991/ijim.v13i08.10730.

Puad, L. M. A. Z., \& Ashton, K. (2020). Teachers' views on classroom-based assessment: An exploratory study at an Islamic boarding school in Indonesia. Asia Pacific Journal of Education, 1-13. https://doi.org/10.1080/02188791.2020.1761775.

Retnaningsih, W. (2013). Applicability of model Assessment for Learning (AFL) in classes of vocabulary and pragmatics in English teaching learning at STAIN Salatiga. Register Journal, 6(1), 53-76. https://doi.org/10.18326/rgt.v6i1.53-76.

Rodliyah, R. S. (2018). Vocational school EFL teachers' practices of integrating ICT into English lessons: Teachers' voices. Indonesian Journal of Applied Linguistics, 8(2), 418-428. https://doi.org/10.17509/ijal.v8i2.13309.

Safitry, T. S., Mantoro, T., Ayu, M. A., Mayumi, I., Dewanti, R., \& Azmeela, S. (2015). Teachers' perspectives and practices in applying technology to enhance learning in the classroom. International Journal of Emerging Technologies in Learning, 10(3), 10-14. https://doi.org/10.3991/ijet.v10i3.4356.

Sheard, M. K., \& Chambers, B. (2014). A case of technology-enhanced formative assessment and achievement in primary grammar: How is quality assurance of formative assessment assured? Studies in Educational Evaluation, 43, 14-23. https://doi.org/10.1016/j.stueduc.2014.02.001.

Siregar, R. A., \& Amalia, S. N. (2019). Pre-service English teachers' attitude towards HOTS to prepare better assessment. JEELS (Journal of English Education and Linguistics Studies), 6(1), 51-72. https://doi.org/10.30762/jeels.v6i1.1072.

Tarighat, S., \& Khodabakhsh, S. (2016). Mobile-assisted language assessment: Assessing speaking. Computers in Human Behavior, 64, 409-413. https://doi.org/10.1016/j.chb.2016.07.014.

Webb, M., \& Ifenthaler, D. (2018). Assessment as, for, and of twenty-first-century learning using information technology: An overview. In R. Latiner Raby \& E. J. Valeau (Eds.), Handbook of Comparative Studies on Community Colleges and 
Luthfiyyah, R., Aisyah, \& Sulistyo, G. H. (2021). Technology-enhanced formative assessment in higher education: A voice from Indonesian EFL teachers. EduLite: Journal of English Education, Literature, and Culture, 6 (1), 42-54. http://dx.doi.org/10.30659/e.6.1.42-54

Global Counterparts (pp. 1-20). Springer International Publishing. https://doi.org/10.1007/978-3-319-53803-7_37-1.

Yin, R. K. (2017). Designing Case Studies. In Case Study Research and Applications: Design and Methods.

Yin, R. K. (2018). Case study research and applications: Design and methods (Sixth edition). SAGE.

Conflict of Interest Statement: The authors declare that the research was conducted in the absence of any commercial or financial relationships that could be construed as a potential conflict of interest.

Copyright () 2021 Luthfiyyah, Aisyah, and Sulistyo. This is an open-access article distributed under the terms of the Creative Commons Attribution License (CC BY). The use, distribution or reproduction in other forums is permitted, provided the original author(s) and the copyright owner(s) are credited and that the original publication in this journal is cited, in accordance with accepted academic practice. No use, distribution or reproduction is permitted which does not comply with these terms. 